\title{
Prejudice against Students' Accent at Jordanian Universities
}

\author{
Wael Zuraiq \\ Moh'd Al-Omari \\ Sabri Al Shboul \\ Anas al Huneety \\ Bassil Mashaqba \\ The Hashemite University \\ Jordan
}

\begin{abstract}
The basis of the analysis is to examine the reaction towards comments which are used by students to disapprove of each other's local accent and thus rejecting certain identities. This study reports on a representative sample of nine representative students (out of 40 students at four universities). The researchers interviewed the students using open-ended questions. Interviews lasted from 20 to 30 minutes. Forty participants (20 males and 20 females) were interviewed. About $70 \%$ of the interviewees supposed that comments on accent implicated sociolinguistic prejudice. And only 30\% did not believe that comments were subjective, and assumed that such comments do enhance the successful communication process by trying to accomplish using a homogenous accent that is appropriate for all students. The study shows students' identities as associated with both institutional contexts and group affiliations. And the findings are discussed within Social Identity Theory (Tajfel and Turner's, 1986) and Communication Accommodation Theory (Giles 1980 and works after).
\end{abstract}

Keywords: Accent, Prejudice, Arabic, Identity, Comments.

\section{Introduction}

Communication Accommodation Theory (Giles 1980 and works after) suggests that there is a connection between language, context, and identity. It focuses on social convergence and/or identity divergence. On the one hand, individuals may adjust communication to minimize social differences. On the other, individuals may disagree in their communication to emphasize a unique identity. The sociolinguistic consequences, either convergence or divergence, are crucial to our understanding of human behavior. In Communication Accommodation Theory (CAT) there is a link to socio-psychological theory to clarify why communicators converge or diverge across the continuum of languages, dialects, accents. CAT is also linked to social identity theory (Tajfel and Turner's 1986 and Turner \& Reynolds 2011) where individuals exhibit both in-groups relations and out-groups relations. Group membership or attachment can be conveyed via speech; speakers implement convergence and/or divergence to indicate obvious group uniqueness to attach importance to the speaker's identity. The theory of intergroup distinctiveness (Tajfel 1974 and other works) posits that if speakers of diverse groups are in contact, they tend to evaluate themselves on scopes that are very significant to them such as individual attributes, abilities, and material assets. With such evaluations, speakers try to sound different from the out-group, and sometimes within the same group, to stress their social identity. Since language style is an essential issue in defining sociolinguistic groups, divergence is regularly utilized to highlight intergroup uniqueness if group affiliation is an outstanding question or if the speaker's identity is being endangered. CAT is applied to communication within dissimilar and similar social groups such as cultures, generations, and genders (see Giles \& Ogay, 2007).

The fact that Arabic is diglossic across all Arab countries may generate accent cataloging. In our Jordanian universities, there are seven core heard accents: Bedouin, Ghorani, Rural, Urban (Palestinian), Egyptian, Iraqi, and Syrian. Jordanian students or other students who exhibit local or regional accents that can be "inappropriate" as evaluated by other students on the same campus possibly will be confronted with social prejudice and group stigma. Such notions may create sociolinguistic condemnation in the context of educational settings. Bedouin accent is a generally an established accent of "praiseworthy" tribes (e.g., Bani Hassan Bedouin, Bani Saxar, Shammari, Anazi, Abbadi, Hweitat, etc ...). For details of the linguistic situation of Jordanian dialects read Sakarna (2002). Gorani accent is used by black farmers across Jordan valley extending over about $100 \mathrm{Km}$ strip juxtaposed to River Jordan. This accent is usually underreported in linguistic analysis and many Jordanians are even not aware that it exists. Rural accent is widely spread in cities and villages heavily populated with the accent of the native villagers in that northern part of the Jordan. Urban dialect can be considered as the prevailing accent in Amman and some scholars call it 'Ammani Arabic'. And it is honored by the urbane and classy community in western Amman 
and to a lesser extent in other cities. The number of Egyptians, who work in Jordan, is 250 thousand. However, these Egyptian workers come from different parts from Egypt and therefore representing different accents of Egyptian Arabic. After the Iraqi wars, an estimated 200,000 refugees are now permanent residents in Jordan, not including the ones who come and leave regularly. The first wave of Iraqi refugees came to Amman in the aftermath of the Second Iraqi War. A lot of Iraqi refugees represent Baghdad's accent. And the number of Syrian migrants and their descendants in Jordan is estimated at around 700,000 people. They also represent different accents across Syria. There also other minor accents with a very limited number of speakers like the Druze accent. Since there are several dialects and accents in Jordan (Hammarström, 2017), we observe so much sociolinguistic diversity. We observe that students from different dialects and accents do tend to speak out their group distinctiveness on campus since they mingle with their natural peers most of the time. And we also observe that pride in group identity manifests itself across all Arabic dialects and accents. Diverse students at Jordanian universities are more likely to emphasize their affiliation to their group via overvaluing the shared lifestyle, customs, and inevitability the pleasure of emphasizing heritage accents. No research has examined the outcome of accents in Jordan on students' attitudes. The distinction of accents combines four mechanisms: The sounds of the phonetic inventory, distinction in intonation, lexical stress, and assimilation patterns. Table 1 shows a basic segmental difference in the phonetic inventory of the basic seven dialects and accents of students at Jordanian universities; also see Mitchell (1993).

Table 1. The basic differences in the phonetic inventory of students at Jordanian universities

\begin{tabular}{|c|c|c|c|c|c|c|c|}
\hline Standard Sound & Urban & Rural & Bedouin & Gorani & Egyptian & Iraqi & Syrian \\
\hline$\theta$ & $\mathrm{t}$ & $\theta$ & $\theta$ & $\theta$ & $\mathrm{s}$ & $\theta$ & $\mathrm{t}$ \\
\hline d3 & 3 & $\mathrm{~d}_{3}$ & $\mathrm{~d}_{3}$ & d3 & $\mathrm{g}$ & ts & 3 \\
\hline д & d & ð & ð & ð & $\mathrm{Z}$ & д & d \\
\hline$q$ & $?$ & $\mathrm{~g}$ & $\mathrm{~g}$ & $\mathrm{~g}$ & $?$ & $g^{4}$ & $?$ \\
\hline $\mathrm{k}$ & $\mathrm{k}$ & $\mathrm{t} \int$ & $\mathrm{t} \int$ & ts & $\mathrm{k}$ & t5 & $\mathrm{k}$ \\
\hline Emphatic d $^{\varsigma}$ & $\mathrm{d}$ & $ð$ and $\partial^{\varsigma}$ & $\partial^{\zeta}$ & $\partial^{\zeta}$ & $d^{\zeta}$ & $\partial^{\zeta}$ & $d^{\varsigma}$ \\
\hline Emphatic $ð^{\complement}$ & $\mathrm{z}^{\mathrm{S}}$ & $\partial^{\complement}$ & $\partial^{\zeta}$ & $\delta^{\varsigma}$ & $\mathrm{z}^{\mathrm{S}}$ & $\delta^{\zeta}$ & $\mathrm{z}^{\mathrm{S}}$ \\
\hline Emphatic t ${ }^{5}$ & $\mathrm{t}$ & $\mathrm{t}^{\mathrm{s}}$ & $\mathrm{t}^{\mathrm{s}}$ & $\mathrm{t}^{\mathrm{s}}$ & $t^{5}$ & $\mathrm{t}^{\mathrm{s}}$ & $\mathrm{t}^{\mathrm{s}}$ \\
\hline ai & eI & eI & eI and i: & eI & eI & i: & eI \\
\hline $\mathrm{av}$ & ou & əu & əu & วu & ou & ou & ou \\
\hline $\mathfrak{x}$ & $æ$ & $x$ and $a^{\zeta}$ & $\mathrm{a}:$ & $\mathfrak{x}$ & $\mathfrak{x}$ & $\mathrm{a}:$ & $æ$ \\
\hline
\end{tabular}

Moreover, intonation is a natural system of speech production and perception (cf. Gussenhoven 2004). Intonation does express emotions and attitudes. Like musical tunes, intonation represents the rhythm and melody of an accent or a dialect. For a complete analysis of intonation in Arabic accents and dialects see [Alharbi (1991), Alzaidi (2014), Benkirane (1998), Blodgett et al. (2007), Chahal (2001), Chahal and Hellmuth (2014), de Jong and Zawaydeh (1999), El Hassan (1990), El Zarka (2011 and 2017) and other works, Ghazali et al. (2007), Hellmuth (2006 \& 2014), Kulk et al. (2003), Rifaat (2005), and Watson 2002 \& 2011]. Bedouin, rural, and Iraqi tend to exhibit a general intonation pattern which is more likely to be described as rising most of the time whereas Ghorani intonation pattern exhibits a falling intonation. Urban, Egyptian, and Syrian are usually showing a very melodic $\left(\mathrm{H}^{*} \mathrm{~L}\right)$, pleasing, intonation pattern which is considered cheerful to many Arabs. El Zarka (2017) concludes that the question of variation in Arabic intonation is very complex since different studies used different methods and different theoretical frames.

El Zarka (2017:25) states that "the collaboration of the descriptive linguist who collects a large corpus of sociolinguistically stratified naturally occurring data and the prosody expert who applies various methodologies involving experimental design, acoustic investigation, and statistical methods will help to close the knowledge gap and complete the picture of into national variation in Arabic."

Lexical stress is also an extraordinary central concern to accent differences since stress is vital to mental access. Watson (2011) found that Arabic varies in its rhythmic grouping of light syllables. And that the socially and geographically diverse regions result in differences in lexical stress assignment. Stress assignment depends on both the syllable position and syllable weight. However, Watson found that dialects and accents may vary in the distribution of syllable types because of many phonological processes such as syncope and epenthesis, the leftmost edge of stress, the rhythmic grouping of syllables, stress interaction, and lexical information affecting stress. Assimilation patterns are also central to the signaling of accent detection. Phonological assimilation takes place within a word or cross word boundaries. It occurs between both vowels and consonants. 
A wide spectrum of phonological features governs it: place, manner, voicing, pharyngealization, and nasalization. Studies on phonological assimilation across dialects and accents present cross-dialectal data such as Watson (2002), Zuraiq and Zhang (2006), and Aldubai (2015).

It is normal to endorse varied accents given that Arabic dialects and accents are spoken in diverse ways in more than 20 different countries. Yet, in nearly all Arab countries, teaching is regularly dependent on Standard Arabic or what is called 'Educated Arabic'. The main problem in this study is that we do observe that students regularly evaluate the accents of other students and may label them as "unsuitable". Accordingly, these evaluations may generate harmful implications amid an educational setting where "standard accent" is repeatedly viewed as "perfect" (Kelch \& Santana-Williamson, 2002; Beinhoff, 2016). Speakers are being told how to speak (Baratta, 2018). Yet, there is no adequate information, to our best knowledge, that investigates the basic problem of students' reciprocal evaluations. The current analysis possibly will reinforce our awareness of such a fundamental problem which is related to our possible communication inequality. In the present study, it is hypothesized that although Arabs emphasize linguistic equality sine we all relate to standard Arabic, many students feel that their different accents can be a sociolinguistic barrier. Such predisposition is more likely to irritate them during day-to-day communication with other students. The present study also intends to display the actual sociophonetic situation at Jordanian universities to provide educational organizations with information about favoritism practiced by students. The immediate purpose of the study is to observe the reaction of the comments projected by students towards each other to "amend" students' accents whenever accent is considered "inappropriate" by other students. Eventually, the study aims at knowing the nature of such power of manipulative comments on students.

\section{Theoretical Framework}

To our best knowledge, available works are examining the power of comments in English but not in Arabic. The problem of prejudice against different Arabic accents used by students at university campuses is naturally discussed within informal social settings but not academically. Social Identity Theory (Tajfel and Turner's, 1986) deals with the concept that our judgment of 'who we are' relies on the social peer we fit in like our small or extended families, real or imagined tribes, socioeconomic class, and even our sports team). Such affiliations shape our major basis for our self-importance and our sense of psychological and social values. Tajfel \& Turner (1979) examined psychological processes that were projected to assess the binary construct of "us" versus "them. When we have more than one affiliation, we have to evaluate our connection and our identity undergoes a conflict as a consequence of the competing factors. Tajfel $(1974,1981)$ presented a robust philosophy of social identity; he supposed that identity is thoroughly reliant on peer involvement. However, individuals possibly will select to adjust their peer involvement if the claimed peer does not adequately accomplish their constructive identity. Gumperz $(1970,1982)$ and Heller $(1982,1987$, and 1988) supposed that peer affiliation is created and preserved through the verbal system. They observed code-switching between different languages and even among varieties of the same language itself. They established that code-switching does show multiple group affiliations. Many studies (cf. Norton (2000/2013), Cummins (2001), Canagarajah (2004), Heller (2007), Lin (2007), and Clarke (2008) examined linguistic identity as a fundamental ingredient of our group affiliations. They found that the varied language circumstances that speakers can contribute in societal settings place a burden on the meaning of identity 'how we identify our membership to the universe,' and the constructing and restructuring of such membership also inside their environment, and the mindfulness of threats and gains of the potential surroundings. Every time people communicate, they are held accountable; and are exposed to the social powers judging them for being 'acceptable' or not. Consequently, individuals are very concerned about their identity reconstruction and negotiation. Varghese et al. (2005) found that identities were 'multiple' and were in conflict.

Also, it was observed that there are tensions between "declared identity and assigned identity". The argument is that classic approaches do not challenge the notion of multiple group memberships. If some approaches do consider the question of multiple identities, such approaches do not even present unambiguous modeling about societal circumstances that may facilitate code-switching as a tactic. Speakers do show multiple identities.

Similarly, speakers within a single peer may diverge in their scale of elasticity. Giles and Johnson $(1981,1987)$ established a theory of 'ethnolinguistic identity' which concentrates on language as a key symbol of group association and identity. The theory suggested that individuals of a certain group frequently contrast theirs to other out-groups to believe in their exceptionalism and that such exceptionalism empowers their group to achieve impressiveness. But if the affiliation is unattractive, people adjust their approach to fit in another privileged group. If verbal communication via a certain dialect or a certain accent manifests itself as a key sign of a group connection, speakers possibly will acclimatize to the 'fresh' group; and such new affiliation may result in uneven language loss. Students' language identity has become a concern of linguistic research (Gutierrez \& Orellana, 2006; Godley \& Escher, 2012; Haddix, 2010, 2012; Reaser, 2016; Baratta, 2018). Deprez-Sims and Morris (2010) stated that the accent is as obvious as background and skin color. Accents and dialects show an essential function in shaping socioeconomic predictions (Trudgill, 1975). Accordingly, accent intolerance can repeatedly lead to automatically prejudiced social misconduct. 
And control of accent can involve discriminatory admission to certain socioeconomic groups and their social gatherings. The accent might, therefore, be the main source of favoritism. A similar conclusion was reported in the UK, admission rates to privileged universities were influenced by ethnicity (Parel and Ball 2013). Sharma et al. (2019) stated that "an ability to speak with a standard or close-to-standard accent of English (especially Standard Southern British English, SSBE, or 'Received Pronunciation') would be seen as advantageous.

"Students showing a local accent of Arabic may perhaps be deemed objectionable by their classmates at university campuses. For example, both rural accent and Bedouin accent are not considered suitable for classroom standards. There is a noticeable discrepancy between local accent and accent anticipated at a campus, even if the students are distinguished in their academic life (Baratta, 2017). Such an observable fact may threaten students who exhibit a local accent and also a student who has a foreign accent. Formerly, students were required simply to be hardworking learners to gain knowledge effectively and students' identity is unimportant (Nunan, 1988; Woods, 1996). The new reconstruction of student-student relationships focuses on identity as a key element in deciding how language should be thought of since teachers are not neutral contributors to the teaching space (Norton, 2002). Accordingly, the teacher's identity has become a central constituent in the sociolinguistic view of the learning vicinity. Who people are concerning their identity is an intricate question (Casanave \& Schecter, 1997). Identity is usually an unpredictable instrument and is context-dependent (Duff \& Uchida, 1997; Norton Peirce, 1995; Sarup, 1996). Individuals may encounter a struggle between "obligatory identity" and "favored identity" (Buzzelli \& Johnston, 2002). At present, identity is created, continued, and discussed through verbal communication. Varghese et al. (2005: p. 35) named three main arguments for language identity:

1. Identity is manifold, changing, and in conflict;

2. Identity is related to societal, intellectual, and political circumstance;

3. Identity is constructed, sustained, and bargained in the course of communication.

Theoretical perspectives can help us understand the divergent nature of identity. But, to the best knowledge of the authors, there has been no available academic works that deal with the problem of comments given from students to students at Jordanian university. The question of accent prejudice is not generally discussed scholarly at Jordanian universities and might be considered a taboo since students and researchers are less likely to delve into such a problematic issue that divide us rather than unite us. We hope that this study will launch intellectual attempts to handle the problem of comments at Jordanian universities in a frank manner. Accents linked to superior socioeconomic class are usually alleged to be more sophisticated. On the contrary, substandard accents or dialects are not supposed to indicate sophistication. Giles, Baker, and Fielding (1975) and Dixon, Mahoney and Cocks (2002) both discovered that even when most communication features are 'standard' (syntax, terminology, language style), a lecturer with the other accent like Birmingham accent, for an example, was evaluated to be not scholarly like an RP speaker. Our qualitative study on university students, therefore, would provide an innovative account of existing comments and therefore attitudes to some major Arabic dialects and accents.

\section{Methodology}

\section{Research design}

Given that the present study concentrates on students' performance and the learning environment inside university campuses, and since the study is not examining the cause and effect of accent prejudice, a qualitative approach is applied. (Salkind 2006).

\section{Sampling method}

Because we needed a group of students who would present detailed information, stratified sampling was used. Stratification is the method of assigning participants into standardized subgroups before sampling. The strata describe distributions of the population. Every student in the population is assigned to one and only one stratum. Subsequently, random sampling is used inside each stratum. The purpose is to enhance the sampling accuracy by minimizing error. The population of the present study is all university students at Tafila University, University of Jordan, Yarmouk University, and the American University of Madaba. Since the study required reflecting the diversity of students, it integrated students representing accent groups.

\section{Research instrument}

Researchers started with basic questions before introducing the central questions. Interviews lasted 20 to 30 minutes. Researchers documented immediate comments and observations throughout and after every meeting. The remarks were then translated into English. Forty B.A. students (20 males and 20 females) were met. The age of participants ranged from 18 to 22. During interviews, questions were open-ended and easy to comprehend. All interviews were held in a calm scene, without any external interruptions and avoided possible offensive body language. 


\section{Questions about the recruitment interview are:}

1. How do you feel about other students generally?

2. How do you describe your dialect or accent?

3. Do you think your accent is suitable at campus?

4. Have you ever been told you speak with an unusual accent?

5. How do you usually respond when the other students comment on your accent?

6. Do you feel that there is anything else to discuss with your accent?

\section{Data collection technique}

The main techniques which were used to collect data include observation, visual analysis and interviews. Interviewing focus groups is the most popular technique. Semi-structured interviews were employed for their flexibility in permitting the students to provide detailed answers on factual situations that were important to them although such situations might not initially have been considered relevant by the researchers themselves. Interviews are thus dynamic. First, students who had recently been selected by stratified sampling were encouraged to contribute to the study willingly. Then students who agreed to provide their feedback via the questions of the interview were educated about the study (intention, length of dialogue, and offer for withdrawal from the interview, possible benefits, and risks) and students were guaranteed confidentiality and anonymity of their answers to encourage them to build trust in the whole course of action.

\section{Data analysis}

The analysis of data comprehensively depended on the communication with students since the study is qualitative in nature; such an approach facilitated research to explore the veiled thoughts and to find good explanations for such attitudes. By analyzing data; all the facts, hypotheses, and notions were also documented. The main phase in the qualitative data analysis process is coding. The process of coding accomplished manually to read and categorize data. Then we identified the patterns from the data. Consequently, we sorted the data into 2 main categories:

1. Data from students who felt that comments on accent were prejudiced.

2. Data from students who felt that comments on accent were not prejudiced.

\section{Findings}

The qualitative interview data were then transcribed and categorized into themes as follows;

1. Remarks from students who felt that comments on accent were prejudiced.

2. Remarks from students who felt that comments on accent were not prejudiced.

\section{Remarks from students}

A representative selection of remarks provided by Arabic students who received comments on their accent by other students is presented.

Remarks provided by students who felt that comments were prejudiced.

Student A

Student A has a Jordanian Bedouin accent spoken in the southern region. He reported:

Every time I speak, many students assume that I am an outsider. They always say that my Arabic is very hard to understand. And that I speak incorrectly. They add that most students at university would hesitate to communicate with me because of my very fast and incomprehensible words and sentences. Thus, I always feel very uncomfortable to communicate. One student even said once that I should avoid talking because I impede the fluency of jokes. I always suffer because of these prejudiced comments. My tribe has been in Jordan for centuries and we have been speaking our accent centuries ago. Our poets still compose noble Nabateans poems, and my ancestors built Petra. How come I am an outsider now?

\section{Student $B$}

Student B has a Jordanian Rural accent spoken in the northern region (Irbid). He reported:

I do not think that my accent is embarrassing at all. It is the accent of the native people. Some students do tell me over and over that my accent shows my rural identity. I usually insist on speaking my accent the way my parents and grandparents speak it. There is nothing wrong with it but some students do not like it because they think that rural people are inferior. I wonder why they think so. It is only their fake arrogance since most of them live in cities and they think that they are more civilized than we are. It seems that they attach civility only to being an inhabitant of the city. I think civility has nothing to do with the place of domicile. They do not know that civility means politeness, friendly, and being nice and just to everybody.

\section{Student $C$}

Student $\mathrm{C}$ has a Jordanian Urban from Amman. She reported: 
Students always tell me that my accent is too stylish. However, I think my accent is a normal part of me, and I do not intend to sound stylish. The strange thing is that so many female students always try to imitate my way of speaking even though they criticize me for speaking in that way. I feel that students are simply subjective because they think I am rich and classy. I am not rich, and I come from a very humble family, but my accent is my accent. I cannot change my tongue to another accent since I acquired my accent from my parents and relatives, and this is the way how we speak at home and everywhere.

Student $D$

Student D has a Jordanian Ghorani from the Jordan valley. She reported:

Students always laugh at my accent. I feel so offended by such students, and I tend to stop speaking whenever I feel that I would say something that will encourage their curiosity about my accent. The fact that I come from a black family working hard in The Jordan Valley farms makes students deal with me in a very cruel way. I always get comments from other students about my accent. They claim that my accent is out-of-date. So many students never heard this accent, but this does not entitle them to criticize me for something that I am not responsible for. Some students are less likely to ask me to join the study groups since they think I am not smart. I lost my self-confidence, and I wanted to quit school several times but my family kept supporting me not to do so. Now I feel more comfortable with online classes after the corona virus pandemic.

Student E

Student E is Egyptian. She reported:

I have been in Jordan for 2 years. My first year was a bit difficult for me for different reasons. I suffered because I could not fully understand my colleagues although they could understand me. It seems that students at the university are familiar with Egyptian Arabic, but I was not that familiar with their Arabic. However, they laughed sometimes at me when I was talking. When I asked them about it, they would say that I remind them of the funny comedians they used to watch on TV. I felt very offended because I was talking seriously, but they did not take it seriously. I usually tell them to deal with me seriously, but they insist on turning the whole talk about words that sound funny.

I never thought that my Arabic is funny, but they did. I tried to mimic their Arabic, but I do not know why I always fail to do so. Some students told me that Egyptian Arabic is the Arabic of belly dancing and corrupt songs. This made me feel so annoyed.

\section{Student F}

Student $\mathrm{F}$ is an Iraqi. She reported:

I never felt that my accent is an issue until I came to this university. Of course, I was targeted several times by other students because of my accent. Both male and female students keep telling me that my accent is so too strong for a female. I did not know what they meant until a close friend told me that a female should speak in a 'soft' accent that is different from men's 'rough' accent. She told me that my consonants and vowels are very strong and I should simplify my accent a little bit. Moreover, she added that I should sound more to like a Lebanese lady.

Student G

Student G is Syrian. He reported:

Every time I speak, students ask me "Are you Syrian? I respond politely by saying that I am a new student. When students talk to me, they insist to mimic my way of speaking certain words since they have been watching Syrian drama on TV for decades, and they know how to tease me by that. I try my best not to go into details of my accent to avoid negative comments and tactless criticism. Male students told me once that my accent is excellent for women but appalling for men. I hated such an inconsiderate evaluation of my natural accent.

2. Remarks provided by Arabic students who took no issue:

Student $H$

Student $\mathrm{H}$ has a Jordanian Urban from Amman. He reported:

Some students do make negative comments on my accent, and they say that it is not suitable for a man. However, I think they usually comment on my accent and the accent of other students in a reciprocal manner. I think this is a normal thing among university students since everybody is doing it, and I do not consider it a real problem. I think that most students are trying to communicate funnily. It is a habit at a university that students criticize each other openly. The belief is that if we are frank with each other, then we are closer to each other. Some very close friends of mine will regularly call each other by very impolite words such as animal, stupid, aberrant, abnormal, and so on.

Student I

Student I is Syrian. She reported: 
Most of the students may say some bizarre words about my accent. However, I do not usually respond to them because I think that all people who may speak an unusual accent will be subjected to such disturbing comments. I do not feel bothered by such comments since I am a positive person, and I try always to neglect the issue by telling a joke on my accent itself. Other students would laugh and the whole situation turns into a friendly setting. I did it many times and it worked.

\section{Discussion}

First, the representative token of the seven students took students' comments negatively whereas the last two took no issue. The first group supposed students reacted in a prejudiced manner, and they believed that such prejudice is a sign of a harmful approach toward their own identity. Student A said that negative comments against his accent made him feel an outsider even though he knows that he and his tribe are the native inhabitants of the southern territory of Jordan. He felt uncomfortable with such comments on his accent. And he experienced marginalization although he is aware of the long-established repertoire of his tribes' noble poetry. Usually, Bedouins are very proud of their traditions, poets, and origins. They classically appraise nomadic life over any other approach of life, they are proud of historic philanthropic leaders, and they insist on social and judicial independence. Student B is also a native village dweller who is proud of his long-established rural accent through Jordanian history. He thinks that negative comments against his rural accent are quite associated with the socioeconomics of the relatively poor villages. He considers such comments as a reflection of the arrogance of the students living in the cities. Then, student $\mathrm{C}$ was criticized for her markedly stylish accent where some students feel that sounding excessively stylish is a way of faking socioeconomic status and/or bragging which are both condemned in Islamic teachings. Student D has been feeling insulted by such inconsiderate comments where students describe his accent as old-fashioned. She was even not welcome to join group studies. And this resulted in even losing her self confidence, and now she is more relaxed with on-line classes. Unlike the first four students, the other three students are not Jordanians.

Student $\mathrm{E}$ revealed that he experienced language prejudice because he was not considered funny all the time even though he was serious, and he did not feel comfortable about comments claiming that his language is a language used for "corrupt" activities. And Student F was also targeted a few times by other students because of her language. Her accent was considered "masculine". Students even told her how she should speak and that she should speak like a Lebanese lady. On the other hand, student G was mocked by students' negative comments that his accent is suitable for women but not men.

The last two students ( $\mathrm{H} \& \mathrm{I}$ ) took no issue since student $\mathrm{H}$ considered comments on accent normal reciprocal conduct that is practiced by everybody on campus which intends to ease communication between diverse students via humorous tactics. And student (I) was not bothered by negative comments since she acted in a positive-thinking approach by turning the issue into a sociable talk. From a psychological point of view, prejudice has been recognized as a basic feature of our cognition because of the stress of mental processing and motivated emotions (Bless, Fielder and Strack 2004).

Students are generally biased for different reasons: their acceptance of diversity (Fuertes et al. 2000), their enthusiasm to control bias (Dunton and Fazio 1997) and their ideas about the presence of bias in a certain place (Swim et al. 1995). The level of language divergence is a function of the degree of student's lexical inventory with the contextual dynamics maximizing the salience and positiveness of desired unique or local identity. Divergence usually represents the need for positive distinctiveness. However, divergence can also be approved to smooth the progress of comprehension. For example, students can deliberately overstate their accent to indirectly teach interlocutors about it. This function may encourage other students to adjust their accent. Divergence (Maintenance) is also intended to remind students of 'non-shared' group memberships; and consequently avoiding misattribution. It is also used to emphasize identity as differentiated by socioeconomic inequality. Giles et al (1973) found that divergence generally evokes negative reactions but not always. Social norms may establish the positive or negative judgment of the speaker. Accordingly, Divergence may be only negative if it is used to serve negative purposes. We can state that divergence/maintenance may entail emotional and cognitive purposes. However, there may be other conflicting or intervening variables that may hinder the power of our evaluation such as our tendency to overvalue the weight of such factors like personality, effort, and intent (see Varghese et al 2005). The processes of self-presentation and impression management (Giles \& Street, 1994) entails that speech strategies develop from the images which speakers desire to express. Consequently, communication controls the impressions to generate positive impressions to socially influence others by using a standard and/or a prestigious accent. It is used to guarantee social power and influence. The relationship between the individual and the group is a complex one. Even that we do share beliefs and issues of loyalty, students may belong to continuously changing and multiple group classifications. And individuals do rate personal identity more. Speakers do employ accent to signal solidarity with their local group. For instance, the national boundary suggests that we have to determine who is a native citizen and who is not in a country with lots of refugees; refugees who arrived decades ago and refugees who came only 10 years ago after the 'Arab Spring'. This geopolitical boundary linguistically controls the whole context of divergence (who diverges, when to diverge, where to diverge, and to what degree). 
Our partial theory (as part of the whole theory of CAT) here in this study is that acceptance or rejection of students' accents are negotiated throughout the speech, before and after, by depending on the strength of the sociohistorical context of shared and non-shared traditions and values. Such shared and non-shared sociohistorical values and tradition swill eventually govern the dynamics of accommodative and non-accommodative approaches that students may adopt. Although Jordan is relatively a small country, the demography is very diverse and complicated because of extensive strata; these strata developed from the instability of social, economic, geopolitical, educational, historical contexts across the previous century. Moreover, regulating social distances among such diverse populations can be attained via adopting meticulous accent codes such as patterns of consonantal assimilations, variation of lexical stress patterns, slow and fast speech rhythm, and patterns of intonation with the intention of appearing distinct from other students. Speakers do employ accent to signal solidarity with their local group.

When speaker diverges, they do maximize the distinction and this may often entail unconstructive and even intimidating conduct. However, this does not necessarily mean that there is a direct connection between intention and accent behavior. Accent tactics and strategies may adjust during the line of communication. Although there could be an obvious negative history between most of the refugees from different geopolitical territories, some students may choose to adjust (converge) during the line of communication. The reasons could be that the student is not feeling threatened by the other accent and/or if the speaker does not approve that the other student is, in fact, different in the first place. No one can claim that the amount of sociohistorical distance is constant across all groups of students or even within the same speaker herself/himself during a particular stretch of communication.

Some students are more likely to accommodate the accent behavior of the dominant group and that's maybe why some speakers did not take issue at all with negative comments. Students who took no issue usually do not mind to accommodate to their stereotype of high-status speakers. Accent accommodation (either objective or subjective) may stem from psychological accommodation (motivations to converge or diverge). Such complexity of communication involves intricate processes of verbal and nonverbal communication as a strategy for negotiation and restructuring of multiple identities.

\section{Conclusion}

We tried to have a better understanding of the role of accent prejudice at our universities in a very diverse country. The purpose, objective, of the current study, was to examine the observations of the students towards the comments intended to evaluate their accents by other students. Eventually, we aimed at understanding the pressure of remarks on students and understanding what attitudes they may extend. We also wanted to identify the students' identities as linked to both context and group affiliations. All educational institutions in Jordan can be direct beneficiaries of the findings of the present study. Besides, future research should concentrate on class, disability, sexual orientation, gender, and race of university students. Such topics are at the forefront of investigation within sociolinguistics.

Questions of identity are not only relevant to learners, but are also significant to teachers, university administrations, and legislators. On the theoretical level, Accent divergence or accommodation or even overaccommodation is a very dynamic process since speakers may exhibit new thinking such as changes in the dynamics of respect, politeness, courtesy, civility, and or shift of the communicative situations and norms themselves. Moreover, the feedback from the interlocutor may change our hostility into an apology and therefore into accommodation. This means that predicting the course of communication is never a straightforward task.

\section{References}

Aldubai, Nadhim (2015). Sub-dialectal Coronal and Non-coronal Assimilation in Yemeni Arabic. In International Journal of Applied Linguistics and English Literature. 4, 234-248. Doi 10.7575/aiac.ijalel.v.4n.5p.234.

Alharbi, L. M. (1991). "Formal Analysis of Intonation: The Case of the Kuwaiti Dialect of Arabic.." PhD diss., Heriot Watt University, Edinburgh.

Alzaidi, Muhammad S. A. (2014). "Information Structure and Intonation in Hijazi Arabic." PhD diss., Universityof Essex, Colchester.

Baratta, A. (2017). Accent and linguistic prejudice within British teacher training, Journal of Language, Identity \& Education, 16:6, 416-423.

Baratta, A. (2018). Accent and teacher identity in Britain: Linguistic favouritism an imposed identities. London: Bloomsbury.

Beinhoff, B. (2016). Perceiving identity through accent: Attitudes towards non-native speakers and their accents in English. Journal of Second Language Pronunciation, 2(1), 148-152. doi:10.1075/jslp.2.1.07lin.

Benkirane, Thami. (1998). "Intonation in Western Arabic (Marocco)." In Intonation Systems: A Survey of Twenty Languages, edited by Daniel Hirst and Albert Di Cristo, 345-359. Cambridge: Cambridge Universitypress.

Bless, H., Fiedler, K. and Strack, F. (2004) Social Cognition: How Individuals Construct Social Reality. New York: Psychology Press.

Blodgett, Allison, Jonathan Owens, and Trent Rockwood. (2007). “An Initial Account of the Intonation of Emirati 
Arabic." In Proceedings of the XVIth International Conference on Phonetic Sciences (ICPhS), Saarbrücken, Germany, August 6-10, 2007, 1136-1140.

Buzzelli, C. A., \& Johnston, B. (2002). The moral dimensions of teaching: Language, power, and culture in classroominteraction. New York: Routledge Falmer.

Canagarajah, S. (Ed.) (2004). Reclaiming the local in language policy and practice. Mahwah, NJ: LawrencErlbaum.

Casanave, C. P., \& Schecter, S. R. (Eds.). (1997). On becoming a language educator: Personal essays on professionaldevelopment. Mahwah, NJ: Lawrence Erlbaum Associates, Inc.

Chahal, Dana. (2001). "Modeling the Intonation of Lebanese Arabic using the Autosegmental-Metric Framework: AComparison with English." PhD diss., University of Melbourne.

Chahal, Dana, and Sam Hellmuth. (2014). "The Intonation of Lebanese and Egyptian Arabic." In Prosodic Typology:The Phonology of Intonation and Phrasing, edited by Sun-Ah Jun, 365-404. Oxford: Oxford.

Clarke, M. (2008). Language teacher identities: Co-constructing discourse and community. Clevedon, UK:Multilingual Matters.

Cummins, J. (2001). Negotiating identities: Education for empowerment in a diverse society. $2^{\text {nd }}$ Edition. Los Angeles:California Association for Bilingual Education.de Jong, Kenneth, and Bushra Zawaydeh. (1999). "Stress, Duration, and Intonation in Arabic Word-LevelProsody." Journal of Phonetics 27: 3-22.

Deprez-Sims, A., \& Morris, S. B. (2010). Accents in the workplace. Their effects during a job interview. InternationalJournal of Psychology, 45, 417-426. doi:10.1080/00207594.2010.499950.

Dixon, J., Mahoney, B. and Cocks, R. (2002) Accents of guilt? Effects of regional accent, race, and crime type onattributions of guilt. Journal of Language and Social Psychology 21: 162-8. https://doi.org/10.1177/02627X02021002004.

Duff, P. A., \& Uchida, Y. (1997). The negotiation of teachers' sociocultural identities and practices in postsecondaryEFL classrooms. TESOL Quarterly, 31, 451-486.

Dunton, B. C. and Fazio, R. H. (1997) An individual difference measure of motivation to control Prejudiced reactions. Personality and Social Psychology Bulletin 23: 316-26. https://doi.org/10.1177/0146167297233009

El Hassan, S. A. (1990). "Intonation in the Educated Spoken Arabic of Jordan: The Patterning of Accents." Abhath Al-Yarmouk 8(2): 7-31.

El Zarka, Dina. (2011). "Leading, Linking, and Closing Tones and Tunes in Egyptian Arabic: What a SimpleIntonation System Tells Us about the Nature of Intonation." In Perspectives on Arabic Linguistics, 22-23, edited by Ellen Broselow and Hamid Ouali, 57-73. Amsterdam: Benjamins.

El Zarka, Dina. (2013a). On the Interaction of Information Structure and Prosody: The Case of Egyptian Arabic.Habilitation thesis, Karl-Franzens-Universität Graz.

El Zarka, Dina. (2013b). "Pragmatic Functions and the Biological Codes: Evidence from Sentence Topic and Focus in Egyptian Arabic Declaratives." In Prosody and Iconicity, Iconicity in Language and Literature 13, edited by Sylvie Hancil and Daniel Hirst, 109-126. Amsterdam: Benjamins.

El Zarka, D. (2017). Arabic intonation. In Oxford handbooks online, 1-37. Oxford: Oxford University Press.

https://doi.org/10.1093/oxfordhb/9780199935345.013.77

El Zarka, Dina, and Sam Hellmuth. (2008). "Variation in the Intonation of Egyptian Formal and ColloquialArabic." Langues et Linguistique 22: 73-92.

Fuertes, J. N., Miville, M. L., Mohr, J. J., Sedlacek, W. E. and Gretchen, D. (2000) Factor structure and short form of the Miville-Guzman Universality-Diversity Scale. Measurement and Evaluation in Counseling and Development 33: 157-69. https://doi. org/10.1080/07481756.2000.12069007

Ghazali, Salem, Rym Hamdi, and Khouloud Knis. (2007). "Intonational and Rhythmic Patterns Across the Dialect

Continuum." In Perspectives on Arabic Linguistics, 19, edited by Elabbas Benmamoun, 97-122. Amsterdam: Benjamins.

Giles, H. (1973). Accent mobility: A model and some data. Anthropological Linguistics, 15(2), 87-109.

Giles, H. (1980). Accommodation theory: some new directions. In S. de Silva (Ed.), Aspects of linguistic behavior (pp.105-136). York, England: York University Press

Giles, H., Baker, S. and Fielding, G. (1975) Communication length as a behavioural index of accent prejudice.International Journal of the Sociology of Language 6: 73-81. https://doi.org/10.1515/ijsl.1975.6.73

Giles, H., \& Johnson, P. (1981). The role of language in ethnic group formation. In J.Turner \& H. Giles (Eds.),Intergroup behavior (pp. 199-243). Oxford: Basil Blackwell.

Giles, H., \& Johnson, P. (1987). Ethnolinguistic identity theory: A social psychological approach to language maintenance. International Journal of the Sociology of Language, 68, 69-99.

Giles, H., \& Street, R.L. Jr. (1994). Communicator characteristics and behavior: A review, generalizations, and model. 
In M. Knapp and G. Miller (Eds.), The Handbook of interpersonal communication $\quad\left(2^{\text {nd }} \quad\right.$ ed., $\quad$ pp $\left.\quad 103-161\right)$. Thousand Oaks, CA: Sage.

Giles, H. (Ed.). (2016). Communication accommodation theory: Negotiating personal relationships and socialidentities across contexts. Cambridge, England: Cambridge University Press.

Giles, H., \& Ogay, T. (2007). Communication Accommodation Theory. In B. B. Whaley \& W. Samter (Eds.), Explainingcommunication: Contemporary theories and exemplars. New Jersey: Lawrence Erlbaum

Godley, A., \& Escher, A. (2012). Bidialectal African-American adolescents' beliefs about spoken language

expectations in English classrooms. Journal of Adolescent and Adult Literacy, 55, 704-713. doi:10.1002/JAAL.00085.

Gumperz, J. J., \& Cook-Gumperz, J. (1982). Introduction: Language and the communication of social identity. In $\mathrm{J}$.

J. Gumperz (Ed.), Language and social identity (pp. 1-22). Cambridge: Cambridge University Press.

Gussenhoven, Carlos. (2004). The Phonology of Tone and Intonation. Research Surveys in Linguistics. Cambridge:Cambridge University Press.

Gutierrez, K. D., \& Orellana, M. F. (2006). The 'problem' of English learners: Constructing genres of difference.Research in the Teaching of English, 40, 502-507.

Haddix, M. (2010). No longer on the margins: Researching the hybrid literate Identities of black and Latina preserviceteachers. Research in the Teaching of English, 45, 97-123. doi:10.2307/40997086

Haddix, M. (2012). Talkin' in the company of my sistas: The counter languages and deliberate silences of black femalestudents in teacher education. Linguistics \& Education, 23, 160-181. doi: 10.1016/j.linged.2012.01.003

Hammarström, Harald; Forkel, Robert; Haspelmath, Martin, eds. (2017). "South Levantine Arabic". Glottolog 3.0.

Jena, Germany: Max Planck Institute for the Science of Human History.

Heller, M. (1988). Codeswitching: Anthropological and sociolinguistic perspectives. NewYork: Mouton de Gruyter.

Heller, M. (2007). Linguistic minorities and modernity: A sociolinguistic ethnography, (2 ${ }^{\text {nd }}$. edition). London, UK:Continuum.

Hellmuth, Sam. (2006). "Pitch Accent Distribution in Egyptian Arabic." Ph.D. diss., SOAS, London.

Hellmuth, Sam. (2014). "Investigating the Variation in Arabic Intonation: The Case for a Multi-Level Corpus

Approach." In Perspectives on Arabic Linguistics, 24-25, edited by Samira Farwaneh and Hamid Ouali, 63-90. Amsterdam: Benjamins.

Ingham, B. (1982). Northeast Arabian dialects. London: Kegan Paul International.

Kelch, K., \& Santana-Williamson, E. (2002). ESL students' attitudes towards native and non-native speakingInstructors' accents. The CATESOL Journal, 14, 57-72.

Kulk, Friso, Cecilia Odé, and Manfred Woidich. (2003). "The Intonation of Colloquial Damascene Arabic: A PilotStudy." In University o. A. Institute of Phonetic Sciences (ed.), Proceedings, 15-20. Amsterdam.

Liberman, M. (2010). Removing teachers with "accented" speech? Retrieved from http://languagelog.ldc.upenn.edu/nll/?p=2365.

Lin, A. (Ed.) (2007). Problematizing identity: Everyday struggles in language, culture, and education. LawrenceErlbaum.

Lippi-Green, R. (1997). English with an accent: Language, ideology, and discrimination in the United States. NewYork, NY: Routledge.

Manka Varghese, Brian Morgan, Bill Johnston \& Kimberly A. Johnson (2005). Theorizing Language Teacher Identity:

Three Perspectives and Beyond, Journal of Language, Identity, and Education, 4:1, 21-44.

Mitchell, Terence F. (1993). Pronouncing Arabic II. Oxford: Clarendon Press.

Norton Peirce, B. (1995). Social identity, investment, and language learning. TESOL Quarterly, 29, 9-31.

Norton, B. (2000). Identity and language learning: Gender, ethnicity and educational change. London: Longman.

Norton, Bonny (2013). Identity and Language Learning: Extending the Conversation. Bristol: Multilingual Matters.

Nunan, D. (1988). The learner-centered curriculum: A study in second language teaching. Cambridge, England:Cambridge University Press.

Palva, H. (1991). Is there a North West Arabian dialect group? In M. Forstner (ed.) Festgabe für Hans-Rudolf Singer,

zum 65. Geburtstag am 6. April 1990 überreicht von seinen Freunden und Kollegen, Part 1. Frankfurt: Peter Lang: 151-166.

Palva, H. (2006). Dialects: Classification. In: K. Versteegh et al (eds.). Encyclopedia of Arabic Language andLinguistics, 1. Leiden: Brill, 604- 613.

Parel, K. and Ball, J. (2013) Oxford University accused of bias against ethnic minority applicants. The Guardian, 26 February. 
Reaser, J. (2016). Developing sociolinguistic curricula that help teachers meet standards. In K. Denham \& A. Lobeck

(Eds.), Linguistics at school, language awareness in primary and secondary education (pp. 91-105). Cambridge, UK: Cambridge University Press.

Rifaat, Khaled. (2005). "The Structure of Arabic Intonation: A Preliminary Investigation." In Perspectives on ArabicLinguistics, 17-18, edited by Mohammad T. Alhawary and Elabbas Benmamoun, 49-67. Amsterdam: Benjamins.

Sakarna, Ahmad. (2005). The linguistic status of the modern Jordanian dialects. Arabica, 52, 522-543.

Salkind, N. (2006). Exploring research (6th ed.). USA: Pearson, Prentice Hall.

Sarup, M. (1996). Identity, culture, and the postmodern world. Athens: University of Georgia Press.

Sharma D., Levon E., Watt D., Ye, Y. and Cardos A. (2019) Methods for the study of accent bias and access to elite professions. In Journal of Language and Discrimination. vol 3.22019 150-172. doi: https://doi.org/10.1558/jld.39979

Swim, J. K., Aikin, K. J., Hall, W. S. and Hunter, B. A. (1995) Sexism and racism: old fashioned and modern

prejudices. Journal of Personality and Social Psychology 68: 199-214. https://doi.org/10.1037/0022-3514.68.2.199

Tajfel, H. (1974). Social identity and intergroup behavior. Social Science Information, 13, 65-93.

Tajfel, H. (1981). Social stereotypes and social groups. In J. C. Turner \& H. Giles (Eds.), Intergroup behavior (pp.

144-167). Oxford: Basil Blackwell.

Tajfel, H., \& Turner, J. C. (1986). "The social identity theory of intergroup behaviour". In S. Worchel \& W. G.

Austin. Psychology of Intergroup Relations. Chicago, IL: Nelson-Hall. pp. 7-24.

Trudgill, P. (1975) Accent, Dialect and the School. London: Edward Arnold.

Turner, J.C. \& Reynolds, K. J. (2011). Self-categorization theory. In Van Lange, Kruglanski, \& Higgins (Eds.), Handbook of theories in Social Psychology (pp. 399-417). UK: Sage Publications.

Watson, Janet C. E. (2002). The Phonology and Morphology of Arabic. The Phonology of the World's Languages.Oxford: Oxford University Press.

Watson JCE (2011a) Word stress in Arabic. In: Oostendorp MV; Ewen C; Hume E; Rice K The Blackwell companionto phonology, 5, Oxford: Wiley-Blackwell.

Watson, J.C.E. (2011b). 'Arabic dialects': General article'. In: S. Weninger et al. (Eds.). The Semitic Languages: AnInternational Handbook, 1. Berlin: Mouton de Gruyter, 851-896.

Zuraiq, W. and Zhang, J. (2006). 'Phonological assimilation in urban Jordanian Arabic'. In Kansas Working Papers inLinguistics, 28, 33-46. 